\title{
One-Step Isolation of Monoterpene Indole Alkaloids from Psychotria leiocarpa Leaves and Their Antiviral Activity on Dengue Virus Type-2
}

\author{
Jéssica O. Costa, ${ }^{a}$ Rodolfo S. Barboza, ${ }^{\oplus *, a}$ Ligia M. M. Valente, ${ }^{\oplus *, a}$ Thiago Wolff, ${ }^{\oplus a}$ \\ Mário Gomes, ${ }^{\circledR b}$ Blanca Gallo, ${ }^{\circledR c}$ Luis A. Berrueta, ${ }^{\circledR c}$ Iris P. Guimarães-Andrade, ${ }^{d}$ \\ Daniel Gavino-Leopoldino ${ }^{d}$ and Iranaia Assunção-Miranda ${ }^{d}$
}

\author{
anstituto de Química, Universidade Federal do Rio de Janeiro, Av. Athos da Silveira Ramos, 149, \\ Centro de Tecnologia, Bloco A, 21941-909 Rio de Janeiro-RJ, Brazil
}

${ }^{b}$ Instituto de Pesquisas Jardim Botânico do Rio de Janeiro, R. Pacheco Leão, 915, 22460-030 Rio de Janeiro-RJ, Brazil

'Departamento de Química Analítica, Facultad de Ciencia y Tecnología, Universidad del País Vasco/Euskal Herriko Unibertsitatea (UPV/EHU), P.O. Box 644, 48080 Bilbao, Spain

${ }^{d}$ Instituto de Microbiologia Paulo Góes, Universidade Federal do Rio de Janeiro, Av. Carlos Chagas Filho, 373, Centro de Ciências da Saúde, Bloco I, 21941-902 Rio de Janeiro-RJ, Brazil

\begin{abstract}
The leaf $\mathrm{MeOH}$ extract of Psychotria leiocarpa (Rubiaceae) showed in vitro non-cytotoxic and anti-dengue virus serotype 2 (DENV2) activity in human hepatocarcinoma cell lineage (HepG2). A one-step and cost-effective reversed-phase solid-phase extraction method based on high-performance liquid chromatography (HPLC) parameters allowed the isolation, directly from this bioactive extract, of the monoterpene indole alkaloids: $N$-glucopyranosyl vincosamide (1), vincosamide (2) and strictosidinic acid (3). The chemical structures were characterized based on 1D and 2D nuclear magnetic resonance (NMR), UV and high-resolution mass spectra (HRMS). The methodology has also allowed yielding a polyphenolic-rich fraction that was analyzed by high-performance liquid chromatography coupled to diode array detection and electrospray ionization tandem mass spectrometry (HPLC-DAD-ESI-MS/MS) revealing two flavonol triglycosides $(\mathbf{4}, \mathbf{5})$ and three caffeoylquinic acid isomers (6-8). Compound $\mathbf{3}$ is reported for the first time in P. leiocarpa and all the phenolic compounds (4-8) are described for the first time in the genus Psychotria. Compounds 1-3 showed to be non-cytotoxic and anti-dengue active towards DENV2, highlighting vincosamide (2).
\end{abstract}

Keywords: Psychotria leiocarpa, Rubiaceae, monoterpene indole alkaloids, phenolic compounds, solid-phase extraction, anti-dengue activity

\section{Introduction}

Psychotria L. is the largest genus in the Rubiaceae family with near to 13000 species worldwide, mostly distributed in tropical regions. ${ }^{1}$ The phytochemical studies of the Psychotria spp. described so far have allowed identifying the genus as a source of alkaloids, terpenoids, steroids, flavonoids, tannins, cyclopeptides and phenolic compounds which may be related to the wide variety of biological activities revealed to those species, such as: cytotoxicity, analgesic, antiviral, antifungal and modulator

*e-mail: rodolfosb@iq.ufrj.br; valente@iq.ufrj.br of the activity of the central nervous system. ${ }^{2,3}$ The species Psychotria leiocarpa Cham. \& Schltdl grows as a shrub, being native in Argentina, Paraguay, and Brazil, and in the latter, it can be found in the Northeast and Southern regions. ${ }^{4}$ Extracts from its leaves collected in different locations of the Brazilian territory have been reported as antioxidant, antiinflammatory, inhibitor of the acetylcholinesterase enzyme, antitumoral, analgesic and antimycobacterial. ${ }^{5-9}$ From this species were isolated or characterized, iridoid glucosides, cyclotides, sesquiterpenes (from its essential oil) and the monoterpene indole alkaloids $N, \beta$-D-glucopyranosyl vincosamide (1) and vincosamide (2) ${ }^{6,10-13}$ Compound $\mathbf{1}$, described as the major alkaloid in its leaves, presents 
a broad antioxidant activity, which was considered to be possibly associated to the species protection against oxidative stress such as wounding and UV exposure. ${ }^{12,14,15}$ Compound $\mathbf{2}$ demonstrates anti-inflammatory activity and inhibition of the enzyme acetylcholinesterase. ${ }^{6}$

Dengue is a neglected disease widespread throughout the tropical and subtropical areas and its incidence has dramatically increased in the last decades. ${ }^{16}$ The World Health Organization (WHO) estimates that dengue virus (DENV) infects about 390 million people annually. ${ }^{16}$ It is being considered one of the most prevalent viral infections in the world. ${ }^{17,18}$ In Brazil, it is placed among one of the most serious public health issues. ${ }^{19}$ Currently, there is no antiviral drug approved for the routine treatment of dengue patients. Thus, the discovery of drugs that can exert antiviral activity against DENV, without being toxic to the host cell is highly desirable. Natural products are one of the most important sources for the development of new drugs ${ }^{20}$ and some potential anti-dengue natural compounds have been described. ${ }^{21}$

The solid-phase extraction (SPE) is a technique that has been increasingly used in numerous fields due to its simplicity, cost-effectiveness, and easiness of automation. SPE permits an efficient separation, concentration, and/or pre-purification of analytes and, in semi-preparative or preparative scales it can be advantageous because of its reduced time of analysis, low solvent consumption and possibility of preparing multiple samples simultaneously. ${ }^{22-25}$

As part of our ongoing search for potential anti-dengue agents, the in vitro antiviral activities of several Brazilian Rubiaceae spp. and some of their compounds have been described. ${ }^{25-30}$ In this paper, we report the in vitro noncytotoxicity and anti-dengue virus serotype 2 (DENV2) effects in hepatocarcinoma cell lineage (HepG2), of the crude $\mathrm{MeOH}$ extract of $P$. leiocarpa leaves and of the monoterpene indole alkaloids $N, \beta$-D-glucopyranosyl vincosamide (1), vincosamide (2) and strictosidinic acid (3) isolated by a developed one-step reversed-phase SPE method based on high-performance liquid chromatography (HPLC) conditions. The methodology has also allowed yielding a polyphenolic-rich fraction which was analyzed by online high-performance liquid chromatography coupled to diode array detection and electrospray ionization tandem mass spectrometry (HPLC-DAD-ESI-MS/MS) revealing two flavonol triglycosides $(\mathbf{4}, \mathbf{5})$ and three caffeoylquinic acid isomers (6-8).

\section{Experimental}

General

Methanol $(\mathrm{MeOH})$ and acetonitrile $(\mathrm{ACN})$, both
HPLC grade, were purchased from Tedia (Rio de Janeiro, Brazil). Dimethyl sulfoxide (DMSO) was purchased from Romil Chemical Ltd. (Cambridge, UK). Water was purified in a Milli-Q system (Millipore, St. Louis, USA). Formic acid $(\mathrm{HCOOH})$ (analytical grade) was acquired from Vetec (Rio de Janeiro, Brazil) and glacial acetic acid (AcOH) (analytical grade) from Merck (Frankfurt, Germany) or Vetec (Rio de Janeiro, Brazil). The thin layer chromatography (TLC) analyses were performed in pre-coated silica gel 60 F254 plates (Merck, Frankfurt, Germany) using buthanol (BuOH) (Nuclear, São Paulo, Brazil)/AcOH/water $\left(\mathrm{H}_{2} \mathrm{O}\right)(40: 10: 10 \mathrm{v} / \mathrm{v} / \mathrm{v}$ as mobile phase and irradiation under 254 and $365 \mathrm{~nm}$, and/or NP reagent (diphenylboric acid $\beta$-aminoethyl ester) (Sigma-Aldrich, St. Louis, USA) followed by irradiation under $365 \mathrm{~nm}$, and/or anisaldehyde/sulfuric acid $\left(\mathrm{H}_{2} \mathrm{SO}_{4}\right)$ (SigmaAldrich, St. Louis, USA and Vetec, Rio de Janeiro, Brazil, respectively) to visualize the spots. Nuclear magnetic resonance (NMR) spectra were recorded in $\mathrm{CD}_{3} \mathrm{OD}$ (Cambridge Isotope Laboratories Inc., Tewksbury, USA) in Varian System 500 spectrometer (Varian Inc., Palo Alto, USA) using the solvent as internal standard. Chemical shifts $(\delta)$ are given in ppm and coupling constants $(J)$ in Hz. High resolution mass spectra (HRMS) of the isolated alkaloids were performed in Bruker TOF-maXis spectrometer (Bruker Corp, Billerica, USA). The samples were analyzed in positive ion mode solubilized in $\mathrm{MeOH}$ at $1 \mathrm{mg} \mathrm{mL}^{-1}$. Phenolic standards were supplied as previously described. ${ }^{30}$ All stock standard solutions, in concentrations ranging from 300 to $2700 \mu \mathrm{g} \mathrm{mL} \mathrm{m}^{-1}$, depending on each phenolic compound, were prepared in $\mathrm{MeOH}$. All solutions were stored at $4{ }^{\circ} \mathrm{C}$ in darkness.

\section{Plant material}

The species Psychotria leiocarpa was collected in May 2014 at the Parque Nacional da Serra dos Órgãos, in the municipality of Guapimirim, Rio de Janeiro State, Brazil. Voucher specimen was deposited at the Herbarium of the Universidade Federal do Rio de Janeiro, RJ, Brazil, under number RFA 40646. The collection had the previous permission from SISBIO-ICMBio-MMA-Brazil under number 46504-2. Legal access of the Brazilian genetic heritage component is registered in the SisGen platform under number A9C4B8A.

\section{Extraction and partition}

P. leiocarpa leaves were dried at $40{ }^{\circ} \mathrm{C}$ for $24 \mathrm{~h}$, milled and sieved at $\leq 2.00 \mathrm{~mm}$ particle size. Two different batches of extract were obtained from the dried leaves: first $4.9 \mathrm{~g}$ 
were sonically extracted at room temperature $(15 \mathrm{~min}$ each cycle) with $\mathrm{MeOH}(6 \times 75 \mathrm{~mL})$ and second $9.45 \mathrm{~g}$ were extracted similarly with $\mathrm{MeOH}(10 \times 100 \mathrm{~mL})$. The solvents were evaporated under low pressure, yielding 284.6 and $681.1 \mathrm{mg}$ of dried crude extracts, respectively. The TLC alkaloid profiles of the extracts were identical. The first batch $(284.6 \mathrm{mg})$ was defatted by dissolving it in $40 \mathrm{~mL}$ of $\mathrm{MeOH} / \mathrm{H}_{2} \mathrm{O} 1: 3(\mathrm{v} / \mathrm{v})$ and partitioning with hexane $(10 \times 40 \mathrm{~mL})$. The solvents were removed under low pressure yielding 14.6 and $202.8 \mathrm{mg}$ of the hexane and hydromethanolic fractions, respectively.

\section{HepG2 infection and treatment}

Human hepatocarcinoma cell lineage (HepG2) cells were grown in Dulbecco's modified Eagle's medium (DMEM) (LGC Biotecnologia, Cotia, Brazil) supplemented with 10\% fetal bovine serum (FBS), at $37^{\circ} \mathrm{C}$, in an atmosphere of $5 \%$ $\mathrm{CO}_{2}$. HepG2 cells were infected with DENV-2 (strain 16681) in multiplicity of infection (M.O.I.) of 1 for $1 \mathrm{~h}$ at $37^{\circ} \mathrm{C}$ in $5 \% \mathrm{CO}_{2}$. After infection, the medium was replaced by fresh medium (DMEM with 5\% FBS) with or without $50 \mu \mathrm{g} \mathrm{mL}$ (in DMSO) of the crude extract or the pure compounds (vincosamide (2) was also tested at $25 \mu \mathrm{g} \mathrm{mL}^{-1}$ ) and cultured at $37{ }^{\circ} \mathrm{C}$ in $5 \% \mathrm{CO}_{2}$. The samples (stock $100 \mu \mathrm{g} \mu \mathrm{L}^{-1}$ ) were added to the medium (DMEM with 5\% FBS) to obtain the desired concentration. The final concentration of DMSO in $\mathrm{HepG} 2$ culture was $0.05 \%$, which was also added to the infected and untreated condition. After $48 \mathrm{~h}$ of infection, the culture medium was collected for virus quantification by plaque assay and cellular extracts were used to determine viability (as described below).

\section{Cell viability assay}

The effect of the samples in infected HepG2 cell viability was determined by measuring the metabolization of 3-(4,5-dimethylthiazol-2-yl)-2,5-diphenyl tetrazolium bromide (MTT metabolization assay) by the cells. Cells seeded in a 24-well plate were infected with DENV-2 and treated as previously described. Cytotoxicity and/or proliferative effects were assessed treating uninfected HepG2 cells in the same conditions. Forty-eight hours-post infection cells were washed with balanced salt solution (BSS) prior to the addition of $500 \mu \mathrm{L}$ of $0.5 \mathrm{mg} \mathrm{mL}^{-1}$ MTT (Sigma-Aldrich, St. Louis, USA) in BSS to each well. After $1 \mathrm{~h}$, MTT solution was discarded and the formazan crystals formed were solubilized in each well using $500 \mu \mathrm{L}$ of $0.04 \mathrm{M} \mathrm{HCl}$ solution in iso-propanol ( $\mathrm{PrOH})$. The optical density (OD) of the samples was read at 570 and $650 \mathrm{~nm}$ for background correction.

\section{Virus quantification}

The virus titer in the culture medium of infected HepG2 cells was quantified by plaque assay in baby hamster kidney cells (BHK-21 cells). Briefly, BHK-21 cells were grown in minimum essential medium ( $\alpha$-MEM) (Invitrogen, Life Technologies, California, USA) supplemented with $10 \%$ FSB and seeded in 24-well plates and cultured overnight at $37^{\circ} \mathrm{C}$ with $5 \% \mathrm{CO}_{2}$. Ten-fold serial dilutions of the samples were performed using $\alpha$-MEM and used to infect BHK-21 cells at $37^{\circ} \mathrm{C}$ for $1 \mathrm{~h}$. After this period, $1 \%$ carboxymethyl cellulose in $\alpha$-MEM with $2 \%$ FBS was added and the cells were kept in culture at $37{ }^{\circ} \mathrm{C}$ with $5 \% \mathrm{CO}_{2}$ for five days. Then, the cells were fixed with formaldehyde $4 \%$ and the plaque was visualized by staining with crystal violet ( $1 \%$ crystal violet powder $(\mathrm{m} / \mathrm{v}), 20 \% \mathrm{MeOH}$ and $\left.\mathrm{H}_{2} \mathrm{O}\right)$.

\section{HPLC-DAD analysis}

HPLC analyses were performed in an Agilent Series 1260 equipment with quaternary pump, autosampler, and diode array detector (DAD) (Agilent Technologies, Wilmington, USA) with a LiChrospher RPC18 LiChrocart column $(4.6 \times 250 \mathrm{~mm}, 5 \mu \mathrm{m})$ (Merck, Frankfurt, Germany) coupled to a precolumn Supelguard ${ }^{\mathrm{TM}}$ LC-18 $(4.0 \times 20 \mathrm{~mm}$, $5 \mu \mathrm{m}$ ) (Merck, Frankfurt, Germany). The flow rate was $0.8 \mathrm{~mL} \mathrm{~min}^{-1}$, the injection volume was $10 \mu \mathrm{L}$, and the column oven temperature was set to $40{ }^{\circ} \mathrm{C}$. The sample concentrations in $\mathrm{MeOH}$ were $20 \mathrm{mg} \mathrm{mL}^{-1}$ for the defatted extract and $2 \mathrm{mg} \mathrm{mL}^{-1}$ for the compound $\mathbf{1}$. Prior to the injection, the samples were filtered through a $0.45 \mu \mathrm{m}$ Chromafil R Xtra PVDF membrane (Macherey-Nagel, Düren, Germany). The runs were monitored at $225 \mathrm{~nm}$, and the DAD was set to an acquisition range of $190-400 \mathrm{~nm}$. The data were gathered using the OpenLAB CDS ChemStation Edition software (Agilent Technologies). Ultrapurified water, adjusted to $\mathrm{pH} 3$ with $\mathrm{HCOOH}$ (A), and ACN (B) were used in varying proportions as the mobile phase. The analysis conditions assayed were: $10-20 \% \mathrm{~B}, 0-5 \mathrm{~min}$; 20-22\% B, 5-10 min; 22-24\% B, 10-15 min; 24-26\% B, 15-20 min; $26-28 \%$ B, 20-25 min; $28-30 \%$ B, 25-30 min, and, finally, $30-100 \% \mathrm{~B}, 30-35 \mathrm{~min}$.

\section{SPE procedures}

The SPE in analytical scale was performed in C18 cartridges (500 mg, $3 \mathrm{~mL}$ ) (Applied Separations, Allentown, USA) and in semi-preparative scale was performed in a $30 \mathrm{~mL}$ plastic syringe filled with silica gel C18 (40-63 $\mu \mathrm{m}$, Merck, Frankfurt, Germany) $2.7 \mathrm{~cm}$ inner diameter $\times 3.2 \mathrm{~cm}$ bed high). Both systems 
were coupled to a 12 ports VisiprepTM SPE Vacuum Manifold DL (Supelco, St. Louis, USA). The analytical scale SPE cartridges were previously activated with $5 \mathrm{~mL}$ of ACN, followed by conditioning with $5 \mathrm{~mL}$ of $\mathrm{ACN} / \mathrm{H}_{2} \mathrm{O}$ mixture at the same composition assayed in the first elution. The flow rate was maintained between 1.5 and $3 \mathrm{mg} \mathrm{mL}^{-1}$. The defatted crude extract has been loaded in an aliquot of $1 \mathrm{~mL}$ from a $10 \mathrm{mg} \mathrm{mL}^{-1}$ solution prepared using the same $\mathrm{ACN} / \mathrm{H}_{2} \mathrm{O}$ proportion used in the first elution. The organic solvent was removed from the eluted fractions under reduced pressure at $37^{\circ} \mathrm{C}$ and the water residues were freeze-dried. The optimized SPE procedure in analytical scale was defined as activation step: $5 \mathrm{~mL}$ of ACN; conditioning step: $5 \mathrm{~mL}$ of $10 \% \mathrm{ACN}$; sample application: $1 \mathrm{~mL}$ of defatted crude extract in 10\% ACN; elution steps: (E1) $9 \mathrm{~mL}$ of $10 \% \mathrm{ACN}$, (E2) $9 \mathrm{~mL}$ of $15 \% \mathrm{ACN}$, (E3) $9 \mathrm{~mL}$ of $20 \% \mathrm{ACN}$, (E4) $3 \mathrm{~mL}$ of $24 \% \mathrm{ACN}$, (E5) $3 \mathrm{~mL}$ of $28 \% \mathrm{ACN}$, (E6) $3 \mathrm{~mL}$ of $30 \% \mathrm{ACN}$ and washing step (E7) $3 \mathrm{~mL}$ of ACN.

In the SPE procedures in semi-preparative scale the phase $(10 \mathrm{~g})$ was applied as a suspension in $\mathrm{ACN}$, with the pressure adjusted to $50 \mathrm{kPa}$ below the atmospheric pressure. The total mobile phase volume assayed for each SPE step was adjusted considering the ratio between the elution volumes and the bed volume used on analytical scale. Thus, SPE procedure in semi-preparative scale was defined as activation step: $60 \mathrm{~mL}$ of $\mathrm{ACN}$; conditioning step: $60 \mathrm{~mL}$ of $10 \% \mathrm{ACN}$; sample application: crude $\mathrm{MeOH}$ leaf extract $(100 \mathrm{mg})$ applied onto the column adsorbed in a small amount of the stationary phase; elution steps: (E1) $180 \mathrm{~mL}$ of $10 \% \mathrm{ACN}$ (collected in three sub-fractions of $60 \mathrm{~mL}-\mathrm{E} 1.1, \mathrm{E} 1.2$ and E1.3); (E2) $180 \mathrm{~mL}$ of $15 \% \mathrm{ACN}$ (collected in three sub-fractions of $60 \mathrm{~mL}-\mathrm{E} 2.1, \mathrm{E} 2.2$ and E2.3); (E3) $180 \mathrm{~mL}$ of $20 \% \mathrm{ACN}$ (collected in three sub-fractions of $60 \mathrm{~mL}-\mathrm{E} 3.1, \mathrm{E} 3.2$ and E3.3); (E4) $60 \mathrm{~mL}$ of $24 \% \mathrm{ACN}$, (E5) $60 \mathrm{~mL}$ of $28 \% \mathrm{ACN}$, (E6) $60 \mathrm{~mL}$ of $30 \% \mathrm{ACN}$ and washing step (E7) $60 \mathrm{~mL}$ of ACN. The experiments were performed six times in parallel (total of crude extract $=600 \mathrm{mg}$ ). The correspondent fractions from the parallel experiments were combined by TLC similarities, the organic solvent was removed under low pressure at $37^{\circ} \mathrm{C}$ and the water residues were freezedried. Compounds $\mathbf{1}, \mathbf{2}$ and $\mathbf{3}$ were selectively isolated from E3.2-E3.3, E6 and E2.2-E2.3 + E3.1 fractions, respectively. The TLC and ${ }^{1} \mathrm{H}$ NMR profiles of the E1.1 and E1.2 fractions revealed non-alkaloidal polar compounds. The amounts of the combined fractions are shown in Supplementary Information (SI) section, Table S1.

\section{HPLC-DAD-MS/MS analysis}

The HPLC-DAD-MS/MS analyses were carried out in an Alliance 2695 Waters (Waters Cop., Milford, USA) equipment with a quaternary pump, autosampler, degasser, column oven, diode array detector and equipped with a Phenomenex Luna C18(2) column (Phenomenex, Torrance, USA) $(150 \times 4.6 \mathrm{~mm}, 3 \mu \mathrm{m})$ with a Waters Nova-Pack C18 guard column $(10 \times 3.9 \mathrm{~mm}, 4 \mu \mathrm{m})$ (Waters Cop., Milford, USA). A previously reported gradient program was employed: ${ }^{30} \mathrm{AcOH}-\mathrm{H}_{2} \mathrm{O}(0.5: 99.5 \mathrm{v} / \mathrm{v})$ (phase A) and $\mathrm{MeOH}$ (phase $\mathrm{B}$ ). The applied elution conditions were: 0-2 min, 0\% B isocratic; 2-6 min, linear gradient from 0 to $15 \% \mathrm{~B}$; 6-12 $\mathrm{min}, 15 \% \mathrm{~B}$ isocratic; $12-17 \mathrm{~min}$, linear gradient from 15 to $20 \% \mathrm{~B}$; $17-35 \mathrm{~min}, 20 \%$ B isocratic; 35-90 min, linear gradient from 20 to $35 \% \mathrm{~B}$; $90-136 \mathrm{~min}$, $35 \% \mathrm{~B}$ isocratic, and finally, washing and reconditioning of the column was done. The diode array detector was set at an acquisition range of 250-600 nm and phenolic compound monitoring was performed at 280,320 and $370 \mathrm{~nm}$. The injection volume was $50 \mu \mathrm{L}$. The online MS were obtained on a Micromass (Waters Cop., Milford, USA). Quattro micro triple quadrupole mass spectrometer coupled to the exit of the diode array detector and equipped with a Z-spray electrospray ionization (ESI) source. A flow of $70 \mu \mathrm{L} \mathrm{min}^{-1}$ from the DAD eluent was directed to the ESI interface using a flow-splitter. Nitrogen was used as desolvation gas, at $300{ }^{\circ} \mathrm{C}$ and a flow rate of $450 \mathrm{~L} \mathrm{~h}^{-1}$, and no cone gas was used. A potential of $3.2 \mathrm{kV}$ was used on the capillary for positive ion mode and $2.6 \mathrm{kV}$ for negative ion mode. The source block temperature was held at $120^{\circ} \mathrm{C}$. Full scan mass spectra (MS), within the $\mathrm{m} / \mathrm{z}$ range $50-1000$, were performed in the positive mode at different cone voltages $(15,30$ and $45 \mathrm{~V})$ and in the negative mode at $-30 \mathrm{~V}$. MS/MS product ion spectra in positive and negative modes were recorded using argon as collision gas at $1.5 \times 10^{-3} \mathrm{mbar}$ and under different collision energies in the range $10-40 \mathrm{eV}$ and $-30 \mathrm{~V}$ (for negative) and optimized (for positive polarity) cone voltages. The optimum cone voltages were those which produced the maximum intensity for protonated molecule $[\mathrm{M}+\mathrm{H}]^{+}$and protonated aglycone ion $\left[\mathrm{Y}_{0}\right]^{+}$in the previous MS experiments. The flavonoid aglycone fragment ions have been designed according to the nomenclature proposed by Ma et al. ${ }^{31}$

\section{Results and Discussion}

In order to evaluate the antiviral activity and the cytotoxicity of the crude $\mathrm{MeOH}$ extract of P. leiocarpa leaves, infected and uninfected HepG2 cells were treated with $50 \mu \mathrm{g} \mathrm{mL}^{-1}$ of the extract and assessed cell survival after $48 \mathrm{~h}$ by the MTT assay. DENV-2 infection promoted a reduction of about $55 \%$ of HepG2 viability in untreated condition. This reduction was less prominent when cells 
were infected and treated with the extract showing $28 \%$ of reduction (Figure 1a). Viability of non-infected HepG2 treated with the extract was only slightly decreased, remaining almost $90 \%$ of viable cell. Quantification of DENV-2 at the conditioned medium of infected HepG2 after $48 \mathrm{~h}$ demonstrated a reduction of about $80 \%$ of DENV infectious particles when it was treated with the extract comparing with untreated condition (Figure 1b). These results indicate that compounds present in the $\mathrm{MeOH}$ extract of $P$. leiocarpa leaves have an efficient antiviral activity against DENV-2.
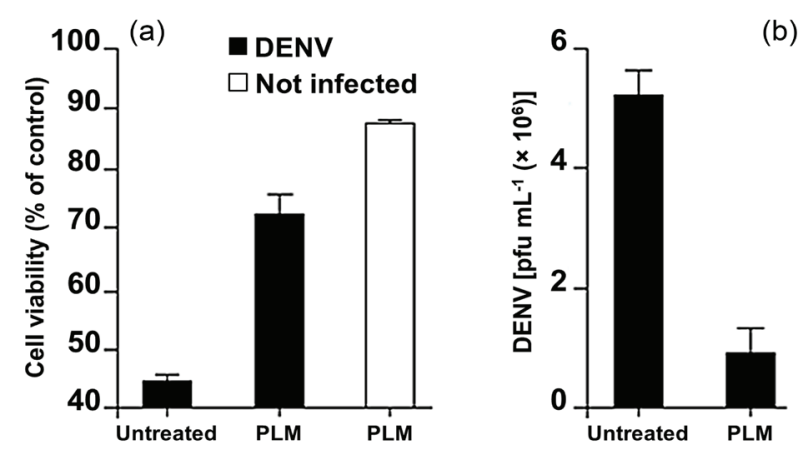

Figure 1. Cytoprotective and antiviral effect of the $\mathrm{MeOH}$ extract from Psychotria leiocarpa leaves (PLM). HepG2 cells were infected with DENV2 16681 or not, then treated with $50 \mu \mathrm{g} \mathrm{mL}^{-1}$ of the extract. Black bars indicate DENV2 16681 infected cells and white bars uninfected cells. (a) Cell viability was assessed by MTT assay $48 \mathrm{~h}$ post infection and results are expressed in percentage of the metabolization of untreated and uninfected HepG2 (control). Non-infected and treated conditions were used as control of cytotoxicity and cell proliferation. (b) Determination of DENV loads in the conditioned medium by plaque assay. The experiments were performed in triplicate of three independent biological replicates and plotted as mean \pm standard error (S.E.M.).

\section{SPE method developing}

The previously described isolations of the monoterpene indole alkaloids from P. leiocarpa leaves employed several classic methodological approaches such as liquid-liquid or acid-base partition followed by chromatography column (CC) in normal or reversed-phase and prep-TLC or semiprep HPLC. ${ }^{6,12,14,15}$ Aiming to optimized the isolation of these alkaloids probably present in our anti-dengue bioactive $\mathrm{MeOH}$ extract of P. leiocarpa, we seek for a onestep isolation procedure based on our previously described expertise. ${ }^{22,25}$ The first approach to access the chemical profile of the bioactive extract was made by TLC, showing three major spots under $254 \mathrm{~nm}$ and a fourth spot (more polar compounds), besides those three, after derivatization with anisaldehyde $/ \mathrm{H}_{2} \mathrm{SO}_{4}$. The HPLC-DAD profile of the defatted extract $\left(\mathrm{MeOH} / \mathrm{H}_{2} \mathrm{O}\right.$ 1:3 v/v fraction) revealed three peaks with UV spectra compatible to those of indole alkaloids $\left(\lambda_{\text {MAX }} 221-225 \mathrm{~nm}\right) .{ }^{12,32}$ The parameters extracted from this HPLC chromatogram: mobile phase composition and elution volume of each peak (Table 1) were used to establish the initial levels of the SPE operational variables..$^{22,25}$

Table 1. HPLC parameters from the major constituents of the defatted extract $\left(\mathrm{MeOH} / \mathrm{H}_{2} \mathrm{O}\right.$ 1:3 fraction) of Psychotria leiocarpa leaves

\begin{tabular}{lccc}
\hline $\mathrm{t}_{\mathrm{R}} / \mathrm{min}$ & $\mathrm{ACN} / \%$ & $\mathrm{~V}_{\text {elution }} / \mathrm{mL}$ & $\mathrm{V}_{\text {elution }} / \mathrm{V}_{\text {bed }}{ }^{\mathrm{a}}$ \\
\hline 2.3 & 20 & 1.8 & 0.4 \\
3.4 & 20 & 2.7 & 0.6 \\
16.8 & 24 & 13.4 & 3.2 \\
34.9 & 100 & 27.9 & 6.6 \\
\hline
\end{tabular}

$\mathrm{t}_{\mathrm{R}}$ : retention time; $\mathrm{ACN}$ : acetonitrile; $\mathrm{V}_{\text {elution }}$ : elution volume; $\mathrm{V}_{\text {bed }}$ : bed volume; ${ }^{a} V_{\text {bed }}=\pi \times \mathrm{r}^{2} \times \mathrm{L}=3.14 \times(0.23)^{2} \times 25=4.1 \mathrm{~cm}^{3}$ (ca. $4.1 \mathrm{~mL}$ ).

The monoterpene indole alkaloid $N, \beta$-D-glucopyranosyl vincosamide (1), previously isolated by classical methods (see isolation details in SI section), was used as reference compound (Figure S1 in SI section). Based on the mobile phase composition range in which the constituents of the defatted extract had been eluted $\left(20 \% \mathrm{ACN} / \mathrm{H}_{2} \mathrm{O}\right.$ v/v to $100 \% \mathrm{ACN})$, the following mobile phase compositions were applied: $20-30 \% \mathrm{ACN} / \mathrm{H}_{2} \mathrm{O}(\mathrm{v} / \mathrm{v})$ and a final washing step with $100 \% \mathrm{ACN}$. The elution volumes of each compound were evaluated as bed volume $\left(\mathrm{V}_{\text {bed }}\right)$ units $\left(\mathrm{V}_{\text {elution }} / \mathrm{V}_{\text {bed }}\right)$ (Table 1). However, the differences of the physico-chemical characteristics between the HPLC stationary phase ( $14 \%$ carbon, $5 \mu \mathrm{m}$ particle size) and that of the SPE cartridge (18\% carbon, 40-60 $\mu \mathrm{m}$ particle size) led us to employ elution volumes smaller than that of the less retained compound $\left(6.6 \times \mathrm{V}_{\text {bed }}\right)$ since we could expect a smaller retention of the compounds in the SPE cartridge (stationary phase with less packing). Thus, the established elution volume was three times the bed volume $(3 \times 1 \mathrm{~mL})$ and a first SPE experiment was designed: (E1) $3 \mathrm{~mL}$ of $20 \% \mathrm{ACN}$, (E2) $3 \mathrm{~mL}$ of $24 \% \mathrm{ACN}$, (E3) $3 \mathrm{~mL}$ of $28 \% \mathrm{ACN}$, (E4) $3 \mathrm{~mL}$ of $30 \% \mathrm{ACN}$ and washing step (E5) $3 \mathrm{~mL}$ of ACN. The TLC monitoring of the yielded fractions evidenced the selectivity of the chromatographic system for the eluted compound(s) in E1 and E3 fractions. However, the eluted compound in E1 fraction also appeared distributed along the E2 to E4 elution steps.

This first SPE procedure was then modified to promote a better separation of the compounds by using less strong initial eluotropic $\mathrm{ACN} / \mathrm{H}_{2} \mathrm{O}$ mixtures: 10 and $15 \% \mathrm{ACN}$ and by increasing the elution volume to three times $(3 \times 3 \mathrm{~mL})$. These optimizations showed to be effective separating the three indole alkaloids and besides, one fraction rich in more polar compounds. A one-step semi-preparative scale-up of isolation (directly from the crude extract) was then designed applying some necessary adjustments. 
A homemade cartridge with $10 \mathrm{~g}$ of RP-C18 stationary phase $\left(3.0 \times 2.7 \mathrm{~cm}, 15-25 \mu \mathrm{m}, \mathrm{V}_{\text {bed }}=\right.$ ca. $\left.20 \mathrm{~mL}\right)$ loaded with $100 \mathrm{mg}$ of the crude extract, which was adsorbed in a small amount of stationary phase instead of the use of $20 \mathrm{~mL}$ of sample solution (to avoid early elution of the constituents on the applying sample step), was used. The first three steps of elution were collected in three sub-fractions of $20 \mathrm{~mL}$ (total $=60 \mathrm{~mL} ; 3 \times \mathrm{V}_{\text {bed }}$ ). The entire process generated 13 fractions, which showed by their TLC profiles the efficacy of the developed method. The experiment was replicated six times in parallel (total of the crude extract $=600 \mathrm{mg}$ ) (Table S1 in SI section). Compounds 1 (40.7 mg), $2(18.4 \mathrm{mg})$ and $\mathbf{3}(56.5 \mathrm{mg})$ (Figure 2) were selectively isolated from E3.2-E3.3, E6 and E2.2-E2.3 + E3.1 fractions, respectively, with high purity, as shown by HPLC-UV and ${ }^{1} \mathrm{H}$ NMR analyses. Their chemical structures were elucidated based upon 1D and 2D NMR, UV, HRMS, and comparison to literature data. ${ }^{6,12,33}$ Compounds 4-8 (Figure 2) were characterized online by HPLC-DAD-MS/MS in the combined E1.1-E1.2 fractions (314.6 mg) (Tables 2 and 3, Figure 3), which showed also to contain free sugars (data not shown).

Anti-dengue activity of compounds 1-3 and polyphenolicrich fraction

The isolated monoterpene indole alkaloids (1-3) and the polyphenolic-rich fraction from the $\mathrm{MeOH}$ extract of P. leiocarpa leaves were used to treat non-infected and infected HepG2 and, cell viability was determined after $48 \mathrm{~h}$ (Figure 4). It was showed that strictosidinic acid (3), $\mathrm{N}$-glucopyranosyl vincosamide (1) and the polyphenolicrich fraction were non-cytotoxic in HepG2, preserving cell<smiles>C=C[C@H]1[C@H](OC(C)=O)OC=C(C(=O)O)[C@H]1C[C@H]1NCCc2c1[nH]c1ccccc21</smiles>

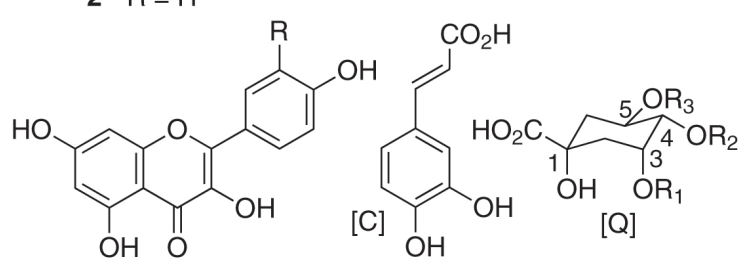

$$
\begin{aligned}
& 4-\mathrm{R}=\mathrm{OH}[+3 \text { hexoses }] \\
& 5-\mathrm{R}=\mathrm{H}[+3 \text { hexoses }]
\end{aligned}
$$

Figure 2. Chemical structures of the isolated monoterpene indole alkaloids (1-3) and of the characterized flavonols $(\mathbf{4}, \mathbf{5})$ and caffeoylquinic acids (CQA) (6-8) from the leaves of Psychotria leiocarpa.

viabilities in about 98, 94 and 107\% (proliferative effect), respectively, comparing to untreated non-infected HepG2. However, vincosamide (2) promoted a reduction of HepG2 viability, resulting in about $83 \%$ viable cells, being more cytotoxic than the crude extract (Figures 1a and 4a). Despite these differences, the treatment of infected HepG2 cells with compounds 1-3 and the polyphenolic-rich fraction promotes a protective effect from DENV induced cell death (about $74,74,83$ and $88 \%$ of cell viability, respectively), compared with untreated infected HepG2 (about 45\% of cell viability) (Figure 4a). In addition, quantification of DENV in HepG2 culture showed that treatment with compounds 1-3 promoted a reduction on DENV infectious particles in the conditioned medium (Figure $4 b$ ). The highest reduction in viral load was observed when infected HepG2 was treated with vincosamide (2) $(99 \%$

\begin{tabular}{|c|c|c|c|c|c|c|}
\hline \multirow[b]{2}{*}{$t_{R} / \min$} & \multirow[b]{2}{*}{ Compound } & \multirow[b]{2}{*}{$\mathrm{UV} \lambda_{\mathrm{MAX}} / \mathrm{nm}$} & \multirow{2}{*}{$\begin{array}{c}\mathrm{MS}^{1} \\
\text { Parent ion }[\mathrm{M}+\mathrm{H}]^{+} \\
m / z\end{array}$} & \multicolumn{3}{|c|}{$\mathrm{MS}^{2}$} \\
\hline & & & & {$[\mathrm{M}+\mathrm{H}-\mathrm{hex}]^{+}$} & $\begin{array}{c}{[\mathrm{M}+\mathrm{H}-2 \mathrm{hex}]^{+}} \\
\mathrm{m} / z\end{array}$ & {$\left[\mathrm{Y}_{0}\right]^{+}$} \\
\hline 20.15 & quercetin-hex-hex-hex (4) & 253,353 & 789 & 627 & 465 & 303 \\
\hline 22.97 & kaempferol-hex-hex-hex (5) & 265,346 & 773 & 611 & 449 & 287 \\
\hline
\end{tabular}

Table 2. HPLC-DAD-MS/MS data of the identified flavonol triglycerides from Psychotria leiocarpa leaves

For the correspondent chromatogram see Figure 3. $\mathrm{t}_{\mathrm{R}}$ : retention time; hex: hexose. See SI section for MS ${ }^{2}$ ions from $\left[\mathrm{Y}_{0}\right]^{+}$.

\begin{tabular}{|c|c|c|c|c|}
\hline \multirow{2}{*}{$t_{R} / \min$} & \multirow{2}{*}{ Compound } & \multirow{2}{*}{$\mathrm{UV} \lambda_{\mathrm{MAX}} / \mathrm{nm}$} & $\mathrm{MS}^{1}$ & $\mathrm{MS}^{2}$ \\
\hline & & & Parent ion $[\mathrm{M}-\mathrm{H}]^{-} \mathrm{m} / z(\mathrm{RA} / \%)$ & Secondary ions $m / z(\mathrm{RA} / \%)$ \\
\hline 15.22 & $3-\mathrm{CQA}(\mathbf{6})$ & 296,317 & $353(100)$ & 191 (100), 179 (ca. 75) \\
\hline 22.60 & 5-CQA (7) & 298,325 & $353(75)$ & $191(100), 179(<5)$ \\
\hline 24.87 & 4-CQA (8) & 302,325 & $353(100)$ & $191(50), 179(60) ; 173(100)$ \\
\hline
\end{tabular}

Table 3. HPLC-DAD-MS/MS data of the identified caffeoylquinic acids (CQA) from Psychotria leiocarpa leaves

For the correspondent chromatogram see Figure $3 . \mathrm{t}_{\mathrm{R}}$ : retention time; RA: relative abundance. 


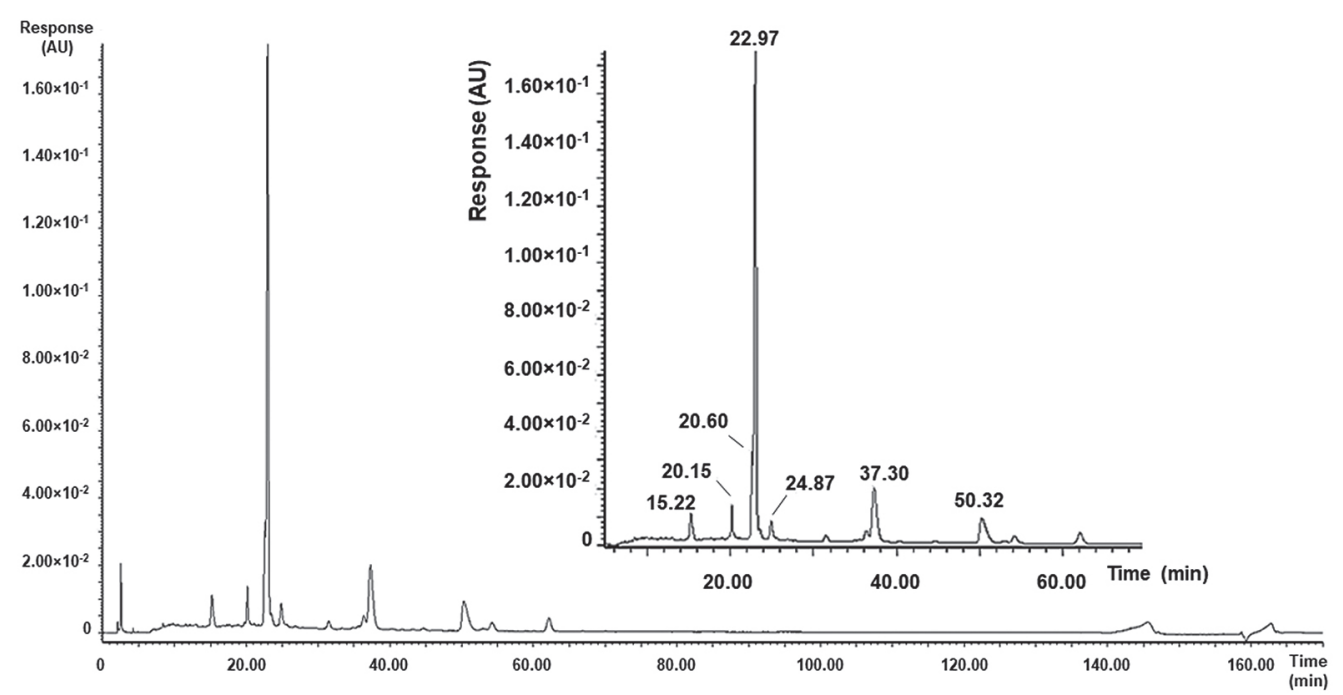

Figure 3. HPLC-DAD profile at $320 \mathrm{~nm}$ of the combined E1.1-E1.2 fractions yielded from the semi-prep SPE experiments from the bioactive extract of Psychotria leiocarpa.
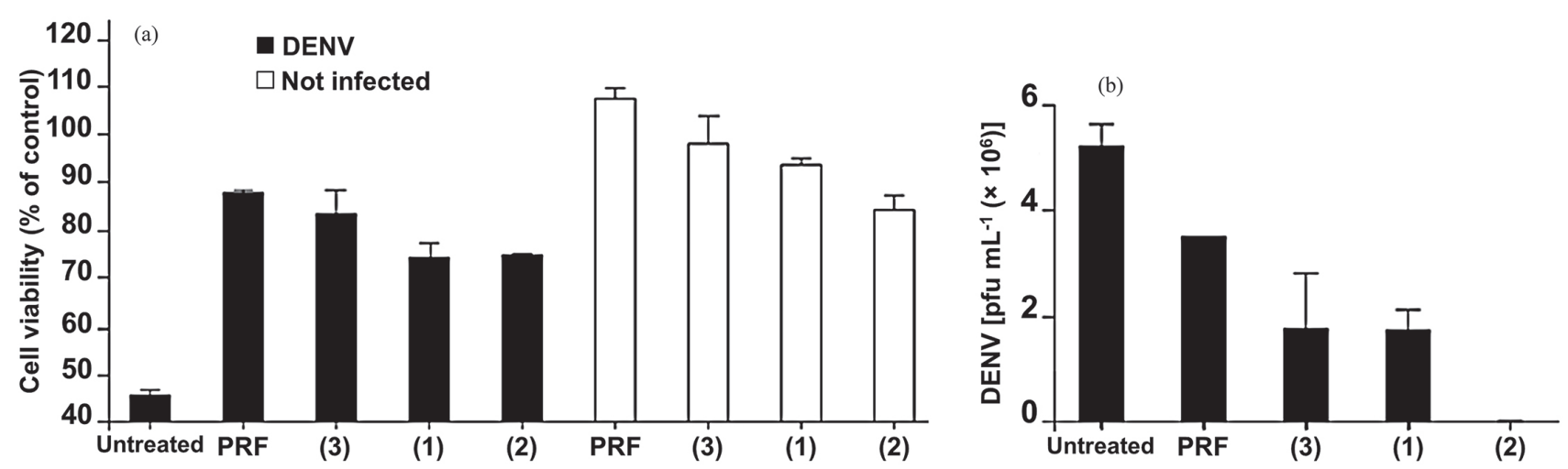

Figure 4. Cytoprotective and antiviral effect of monoterpene indole alkaloids (1-3) and of the polyphenolic-rich fraction (PRF). HepG2 cells were infected with DENV2 16681 or not, then treated with $50 \mu \mathrm{g} \mathrm{mL} \mathrm{mL}^{-1}$ of the extract. Black bars indicate DENV2 16681 infected cells and white bars uninfected cells. (a) Cell viability was assessed by MTT assay $48 \mathrm{~h}$ post infection and results are expressed in percentage of the metabolization of untreated and uninfected HepG2 (control). Non-infected and treated conditions were used as control of cytotoxicity and cell proliferation. (b) Viral quantification in the conditioned medium of infected cells by plaque assay. The experiments were performed in triplicate of three independent biological replicates and plotted as mean \pm standard error (S.E.M.).

of reduction). However, it cannot be excluded that its effect has been determined by the compound cytotoxicity. The polyphenolic-rich fraction showed the lowest antiDENV effect with only $30 \%$ of infectious particles reduction (Figure 4b), which could indicate that its higher cytoprotective effect observed in DENV infected HepG2 (Figure 4a) was mainly associated to its proliferative effect.

Vincosamide (2) with moderate cytotoxicity at $50 \mu \mathrm{g} \mathrm{mL} \mathrm{m}^{-1}$ but high reduction on DENV infectious particles (Figure $4 \mathrm{~b}$ ) was tested at $25 \mu \mathrm{g} \mathrm{mL}^{-1}$ (Figure 5) in order to evaluate the dose-effect on cytotoxicity and on its cytoprotection on DENV infection in HepG2 culture. This lower dose was non-cytotoxic to non-infected HepG2 cells (viability of $94 \%$ when compared to the control). The ability to reduce DENV-induced cell death was preserved. The mortality after infection dropped from 55 to $26 \%$ with treatment, similar to the one observed with the use of $50 \mu \mathrm{gL}^{-1}$ (Figure 4a). These results indicate the potential of vincosamide (2) as anti-dengue agent, despite its relative cytotoxicity.

\section{Polyphenol compounds}

The HPLC-DAD chromatogram of the combined E.1.1-E1.2 fractions from the semi-preparative SPE experiment (Table S1 in SI section) is shown in Figure 3.

The identification of the phenolic compound for which the standard was available was carried out by comparing its retention time $\left(t_{R}\right), U V-V i s$ spectrum, MS recorded in full scan and MS/MS product ion scan mode with those of the standard analyzed under the same conditions. The identity of the other compounds was elucidated using the 


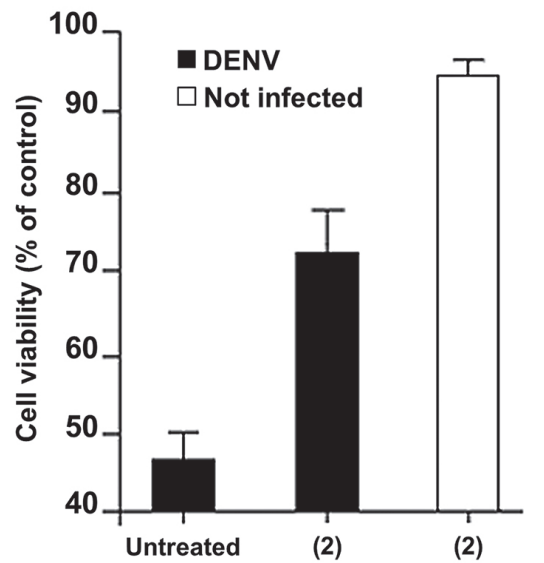

Figure 5. Cell viability of HepG2 after treatment with lower dose of vincosamide (2). HepG2 cells were infected with DENV2 16681 or not, then treated with $25 \mu \mathrm{g} \mathrm{mL}^{-1}$ of the compound. Black bars indicate DENV2 16681 infected cells and white bars uninfected cells. Cell viability was assessed by MTT assay $48 \mathrm{~h}$ post infection and results are expressed in percentage of the metabolization of untreated and uninfected HepG2 (control). Non-infected and treated condition was used as control of cytotoxicity and cell proliferation. The experiment was performed in triplicate of three independent biological replicates and plotted as mean \pm standard error (S.E.M.).

UV-Vis spectra to assign the phenolic class, ${ }^{34}$ the MS full scan spectra in positive and negative modes to identify the $[\mathrm{M}+\mathrm{H}]^{+}$and $[\mathrm{M}-\mathrm{H}]^{-}$ions, the MS/MS product ion spectra using the $[\mathrm{M}+\mathrm{H}]^{+}$ion as precursor to assign the protonated aglycone $\left[\mathrm{Y}_{0}\right]^{+}$and fragmentations observed in both MS/MS product ion spectra using $[\mathrm{M}+\mathrm{H}]^{+}$or $\left[\mathrm{Y}_{0}\right]^{+}$or $[\mathrm{M}-\mathrm{H}]^{-}$. Loss of 132,146 or 162 Da would be an indicative of the presence of pentose, deoxyhexose or hexose, respectively. Additionally, the chromatographic elution order aided in some structural assignments as previously described. ${ }^{35}$ The five identified polyphenolic compounds are shown in Figure 2.

Two flavonol triglycosides were detected: peaks with $\mathrm{t}_{\mathrm{R}}=20.15 \min \left(\mathrm{UV} \lambda_{\mathrm{MAX}}=253,267,353 \mathrm{~nm}\right.$ ) and $\mathrm{t}_{\mathrm{R}}=22.97 \mathrm{~min}$, (UV $\lambda_{\text {MAX }}=265,346 \mathrm{~nm}$ ). The first one $\left(t_{R}=20.15 \mathrm{~min}\right)$ showed protonated and deprotonated molecular ions detected in $\mathrm{MS}^{1}$ scan spectra in positive and negative modes at $m / z, 789$ and 787, respectively. The ESI(+)-MS/MS product ion spectrum obtained using as precursor ion the protonated aglycone $\left[\mathrm{Y}_{0}\right]^{+}(\mathrm{m} / \mathrm{z}, 303)$ revealed the characteristic fragmentation pattern of quercetin aglycone. ${ }^{34}$ The ESI(+)-MS/MS product ion spectrum obtained using as precursor the $[\mathrm{M}+\mathrm{H}]^{+}$ion showed a successive losses of three hexose residues $(\mathrm{m} / z 627$, 465 and 303) (Figure S2 in SI section). The second one $\left(\mathrm{t}_{\mathrm{R}}=22.97 \mathrm{~min}\right)$ showed protonated and deprotonated molecular ions detected in $\mathrm{MS}^{1}$ scan spectra in positive and negative modes at $m / z 773$ and 771 , respectively. The ESI(+)-MS/MS product ion spectrum obtained using as precursor ion the protonated aglycone $\left[\mathrm{Y}_{0}\right]^{+}(\mathrm{m} / \mathrm{z} 287)$ revealed the characteristic fragmentation pattern of kaempferol aglycone. ${ }^{34}$ The ESI(+)-MS/MS product ion spectrum obtained using as precursor the $[\mathrm{M}+\mathrm{H}]^{+}$ion showed a successive losses of three hexose residues $(\mathrm{m} / \mathrm{z}$ 611, 449 and 287) (Figure S3 in SI section). Flavonol diand monoglycosides were reported from Psychotria spp., ${ }^{3}$ however, to the best of our knowledge, it is the first time that flavonol triglycosides are described in the genus Psychotria.

The UV spectra of the compounds related to the chromatographic peaks with $\mathrm{t}_{\mathrm{R}}=15.22 \min \left(\lambda_{\mathrm{MAX}}=296\right.$, $317 \mathrm{~nm}) ; \mathrm{t}_{\mathrm{R}}=22.60 \min \left(\lambda_{\mathrm{MAX}}=298,325 \mathrm{~nm}\right)$ and $\mathrm{t}_{\mathrm{R}}=24.87 \min \left(\lambda_{\mathrm{MAX}}=305,325 \mathrm{~nm}\right)$ suggested the presence of hydroxycinnamic acid derivatives. The MS fragmentation patterns of these peaks were very similar. All of them presented protonated and deprotonated molecular ions detected in $\mathrm{MS}^{1}$ scan spectra in positive and negative modes at $m / z, 355$ and 353, respectively. In addition to these ions, they showed in positive mode the ions at $m / z, 163$ and 173 and, in negative mode, the ion at $\mathrm{m} / \mathrm{z}$ 191. These data suggested the presence of three isomers of the caffeoylquinic acid (CQA) (chlorogenic acid). ${ }^{35} \mathrm{To}$ discriminate the isomers, their ESI(+)-MS/MS product ion spectra using a collision energy of $20 \mathrm{eV}$ were analyzed by using as precursor ion the deprotonated molecular ion $[\mathrm{M}-\mathrm{H}]^{-}\left(\mathrm{m} / \mathrm{z}\right.$ 353). The peak with $\mathrm{t}_{\mathrm{R}}=22.60 \mathrm{~min}$ presented retention time, UV spectrum and MS/MS fragment ions at $m / z, 191(100)$ and $179(<5)$, similar to the 5-CQA standard injected under the same conditions. The elution order in reversed-phase (C18) for the four possible isomers: 1-CQA, 3-CQA, 4-CQA and 5-CQA depends on the number of free equatorial hydroxyl groups in the quinic moiety. ${ }^{36}$ So, 1- and 3-CQA with two free equatorial hydroxyl groups are more hydrophilic and elute before than 4- and 5-CQA isomers (which have just one equatorial hydroxyl group each). Thus, the peak with $t_{R}=24.87 \mathrm{~min}$ is probably the 4-CQA and the peak with $t_{R}=15.22$ min might be 1 - or 3-CQA. In addition, an intense, usually base peak, fragment ion at $m / z 173$, corresponding to dehydration of quinic acid fragment is preferred for an acyl substituent at $\mathrm{C} 4,{ }^{35,37}$ which confirm that peak with $t_{R}=24.87 \mathrm{~min}$ (MS/MS fragment ions at $m / z, 191$ (50), $179(60), 173(100)$ ) is the 4-CQA. Peak with $t_{R}=15.22$ min presents MS/MS fragment ions at $m / z, 191$ (100) and 179 (ca. 75) compatible to the MS/MS fragmentation profile of the 3-CQA. ${ }^{37}$ This is the first time that caffeoylquinic acids are described in the genus Psychotria.

\section{Conclusions}

The in vitro non-cytotoxicity and anti-dengue virus serotype 2 (DENV2) activity of the $\mathrm{MeOH}$ extract 
of P. leiocarpa leaves and of its monoterpene indole alkaloids 1-3 were herein described. Vincosamide (2) with a preliminary dose-dependent activity inhibiting at $50 \mu \mathrm{g} \mathrm{mL}-199 \%$ of DENV infectious particles in the conditioned medium of infected HepG2 culture can be highlighted among the other isolated alkaloids as a potential anti-dengue agent. An efficient one-step SPE method for isolating the alkaloids 1-3 was developed which allowed optimizing the previously described costly and timeconsuming steps of their isolation. The semi-prep scaleup of this isolation was able to successfully reproduce the results obtained in the analytical scale allowing purifying larger amounts of the bioactive compounds for further studies. Compound $\mathbf{3}$ was isolated for the first time from the species. The methodology has also allowed yielding a polyphenolic-rich fraction which contained two flavonol triglycosides $(\mathbf{4}, \mathbf{5})$ and three caffeoylquinic acid isomers (6-8), all of them characterized for the first time in the genus Psychotria.

\section{Supplementary Information}

Supplementary information is available free of charge at http://jbcs.sbq.org.br as PDF file.

\section{Acknowledgments}

This work was supported by Fundação Carlos Chagas Filho de Amparo à Pesquisa do Estado do Rio de Janeiro (FAPERJ), processes No. E-26/111.373/2014 and E-26/203.225/2017. DGL and JOC thank Coordenação de Aperfeiçoamento de Pessoal de Nível Superior (CAPES), finance code 001, for their fellowships. TW thanks both CAPES and FAPERJ for his fellowships. The authors thank the NMR Lab of the Instituto de Pesquisas em Produtos Naturais, Universidade Federal do Rio de Janeiro for the NMR spectra and MSc Matheus Oliveira, Dr Marcelo M. Pereira and Dr Denise Freire for their support. Technical and staff support provided by SGIker (UPV/EHU, MICINN, GV/EJ, ESF) is also gratefully acknowledged.

\section{Author Contributions}

JOC performed the chemical experiments supervised by LMMV and RSB; IPGA and DGL performed the biological experiments supervised by IAM; MG supervised the collection, performed the identification and herborization of the plant material; TW performed the NMR analyses; BG and LAB performed the HPLC-DAD-MS/MS analysis. LMMV, RSB, IAM, BG and LAB contributed to the writing of the manuscript and its revision.

\section{References}

1. Delprete, P. G.; Jardim, J. G.; Rodriguesia 2012, 63, 101.

2. Calixto, N. O.; Pinto, M. E. F.; Ramalho, S. D.; Burger, M. C. M.; Bobey, A. F.; Young, M. C. M.; Bolzani, V. S.; Pinto, A. C.; J. Braz. Chem. Soc. 2016, 27, 1355.

3. Yang, H.; Zhang, H.; Yang, C.; Chen, Y.; Chem. Biodiversity 2016, 13, 807.

4. Ferreira Jr., M.; Vieira, A. O. S.; Hoehnea 2015, 42, 289.

5. Elisabetsky, E.; Amador, T. A.; Leal, M. B.; Nunes, D. S.; Carvalho, A. C. T.; Verotta, L.; Cienc. Cult. 1997, 49, 378.

6. Formagio, A. S. N.; Volobuff, C. R. F.; Kassuya, C. A. L.; Cardoso, C. A. L.; Vieira, M. C.; Pereira, Z. V.; Bagatin, M. C.; Gauze, G. F.; Inflammation 2019, 42, 1561.

7. Formagio, A. S. N.; Volobuff, C. R. F.; Santiago, M.; Cardoso, C. A. L.; do Carmo Vieira, M.; Pereira, Z. V.; Antioxidants 2014, 3,745 .

8. Moraes, T. M. S.; Araujo, M. H.; Bernardes, N. R.; Oliveira, D. B.; Lasunskaia, E. B.; Muzitano, M. F.; Cunha, M.; Planta Med. 2011, 77, 964.

9. Volobuff, C. R. F.; Formagio, A. S. N.; Oliveira, P. C.; Santos, S. M.; Pereira, Z. V.; Ferreira, D. C.; Cardoso, C. A. L.; Ruiz, A. L. T. G.; Foglio, M. A.; Carvalho, J. E.; Curr. Pharm. Biotechnol. 2019, 20, 302.

10. Matsuura, H. N.; Poth, A. G.; Yendo, A. C. A.; Fett-Neto, A. G.; Craik, D. J.; J. Nat. Prod. 2016, 79, 3006.

11. Andrade, J. M. M.; Biegelmeyer, R.; Xavier, C. A. G.; Bordignon, S. A. L.; Moreno, P. R. H.; Zuanazzi, J. A. S.; Henriques, A. T.; Apel, M. A.; Chem. Nat. Compd. 2010, 46, 649.

12. Henriques, A. T.; Lopes, S. O.; Paranhos, J. T.; Gregianini, T. S.; von Poser, G. L.; Fett-Neto, A. G.; Schripsema, J.; Phytochemistry 2004, 65, 449.

13. Lopes, S.; von Poser, G. L.; Kerber, V. A.; Farias, F. M.; Konrath, E. L.; Moreno, P.; Sobral, M. E.; Zuanazzi, J. A. S.; Henriques, A. T.; Biochem. Syst. Ecol. 2004, 32, 1187.

14. Matsuura, H. N.; Fett-Neto, A. G.; Nat. Prod. Res. 2013, 27, 402.

15. Matsuura, H. N.; Fragoso, V.; Paranhos, J. T.; Rau, M. R.; FettNeto, A. G.; Ind. Crops Prod. 2016, 86, 210.

16. World Health Organization (WHO); Dengue and Severe Dengue, November 2019. Available at: https://www.who. $\mathrm{int} /$ news-room/fact-sheets/detail/dengue-and-severe-dengue accessed in May 2020.

17. Guo, C.; Zhou, Z.; Wen, Z.; Liu, Y.; Zeng, C.; Xiao, D.; Ou, M.; Han, Y.; Huang, S.; Liu, D.; Ye, X.; Zou, X.; Wu, J.; Wang, H.; Zeng, E. Y.; Jing, C.; Yang, G.; Front. Cell. Infect. Microbiol. 2017, 7, 317.

18. Guzmán, M. G.; Kouri, G.; Lancet Infect. Dis. 2002, 2, 33.

19. Secretaria de Vigilância em Saúde, Ministério da Saúde do Brasil; Boletim Epidemiológico 15, vol. 51, 2020. Available at 
https://www.saude.gov.br/images/pdf/2020/April/13/Boletimepidemiologico-SVS-15.pdf accessed in June 2020.

20. Newman, D. J.; Cragg, G. M.; J. Nat. Prod. 2020, 83, 770.

21. Dighe, S. N.; Ekwudu, O.; Dua, K.; Chellappan, D. K.; Katavic, P. L.; Collet, T. A.; Eur. J. Med. Chem. 2019, 176, 431.

22. Barboza, R. S.; Mazzei, J. L.; Valente, L. M. M.; Siani, A. C.; J. Liq. Chromatogr. Relat. Technol. 2014, 38, 532.

23. Poole, C. F.; TrAC, Trends Anal. Chem. 2003, 22, 362.

24. Solid-Phase Extraction: Principles, Techniques and Applications; Simpson, N. J. K., ed.; Marcel Dekker, Inc.: New York and Basel, 2000.

25. Barboza, R. S.; Valente, L. M. M.; Wolff, T.; Assunção-Miranda, I.; Neris, R. L. S.; Guimarães-Andrade, I. P.; Gomes, M.; Chem. Biodiversity 2018, 15, e1700393.

26. Lima-Junior, R. S.; Mello, C. S.; Siani, A. C.; Valente, L. M. M.; Kubelka, C. F.; Nat. Prod. Commun. 2013, 8, 1547.

27. Mello, C. S.; Valente, L. M. M.; Wolff, T.; Lima-Junior, R.; Fialho, L.; Marinho, C. F.; Azeredo, E. L.; Oliveira-Pinto, L. M.; Pereira, R. C. A.; Siani, A. C.; Kubelka, C. F.; Mem. Inst. Oswaldo Cruz 2017, 112, 458.

28. Nascimento, A. C.; Valente, L. M. M.; Gomes, M.; Barboza, R. S.; Wolff, T.; Neris, R. L. S.; Figueiredo, C. M.; AssunçãoMiranda, I.; Phytochem. Lett. 2017, 19, 220.

29. Reis, S. R. I. N.; Valente, L. M. M.; Sampaio, A. L.; Siani, A. C.; Gandini, M.; Azeredo, E. L.; D’Avila, L. A.; Mazzei, J. L.;
Henriques, M. G. M.; Kubelka, C. F.; Int. Immunopharmacol. 2008, 8, 468.

30. Wolff, T.; Berrueta, L. A.; Valente, L. M. M.; Barboza, R. S.; Nascimento, A. C.; Gomes, M.; Assunção-Miranda, I.; Guimarães-Andrade, I. P.; Neris, R. S. L.; Gallo, B.; Iriondo, C.; Phytochem. Anal. 2019, 30, 62.

31. Ma, Y. L.; Li, Q. M.; Van den Heuvel, H.; Claeys, M.; Rapid Commun. Mass Spectrom. 1997, 11, 1357.

32. Sangster, A. W.; Stuart, K. L.; Chem. Rev. 1965, 65, 69.

33. Carvalho Jr., A. R.; Vieira, I. J. C.; Carvalho, M. G.; Braz-Filho, R.; Lima, M. A. S.; Ferreira, R. O.; Maria, E. J.; Oliveira, D. B.; Molecules 2017, 22, 2.

34. Abad-Garcia, B.; Berrueta, L. A.; Garmon-Lobato, S.; Gallo, B.; Vicente, F.; J. Chromatogr. A 2009, 1216, 5398.

35. Clifford, M. N.; Johnston, K. L.; Knight, S.; Kuhnert, N.; J. Agric. Food Chem. 2003, 51, 2900.

36. Clifford, M. N. In Methods in Polyphenol Analysis; SantosBuelga, C.; Williamson, G., eds.; Royal Society of Chemistry: Cambridge, 2003, p. 314.

37. Clifford, M. N.; Knight, S.; Kuhnert, N.; J. Agric. Food Chem. $\mathbf{2 0 0 5}, 53,3821$.

Submitted: October 27, 2019

Published online: June 10, 2020 